\title{
Szérumbiomarkerek akut lumbalis-lumbosacralis fájdalomban
}

\author{
Dénes Kitti dr. ${ }^{1}$ - Arányi Zsuzsanna dr. ${ }^{1}$ \\ Csillik Anita dr. ${ }^{1}$. Simó Magdolna dr. ${ }^{1}$ - Debreczeni Róbert dr. ${ }^{1}$ \\ Tegze Nárcisz dr. ${ }^{1}$ - Bereczki Dániel dr. ${ }^{1,2}$
}

${ }^{1}$ Semmelweis Egyetem, Általános Orvostudományi Kar, Neurológiai Klinika, Budapest ${ }^{2}$ MTA-SE Neuroepidemiológiai Kutatócsoport, Budapest

\begin{abstract}
A porckorongsérvhez és a gerincoszlop egyéb degeneratív elváltozásaihoz társuló lumbalis-lumbosacralis fájdalom patogenezisében szerepet játszik a gyulladás, és feltételezhető, hogy ilyen esetekben egyes gyulladásos mediátorok szintje mérhetően megemelkedik a vérben. A vérben mérhető pro- és antiinflammatorikus citokinek, kemokinek, egyéb szabályozómolekulák és a lumbalis-lumbosacralis fájdalom közötti összefüggéseket értékelő vizsgálatok nagyrészt krónikus derékfájdalomban szenvedők csoportjában történtek, az akut állapotban mérhető biomarkerekkel kevesebb vizsgálat foglalkozott. Az eddigi vizsgálatok alapján a proinflammatorikus TNF $\alpha$, IL6, és IL8 és az antiinflammatorikus IL4 és IL10 citokinek játszanak fontos szerepet a discusherniatiót követő gyulladásos válaszban. A személyre szabott medicina szempontjai szerint fontos lehet az akut betegcsoporton belül alcsoportokat létrehozni az etiológia, a prognózis és a kezelés szempontjából. Amennyiben a különböző proinflammatorikus citokinek segítségével azonosítható lenne egy betegcsoport, amelynél a fájdalom hátterében a gyulladás a vezető ok, akkor ezen betegcsoport valószínúleg hatásosan kezelhető lenne különböző gyulladáscsökkentő készítményekkel. A TNF $\alpha$ inhibitorok és az IL6-inhibitorok hatásosságát lumbalis-lumbosacralis fájdalomban kontrollált vizsgálatokban már elemezték, de további tanulmányokra van szükség. A spinalis degeneráció és az akut lumbalis-lumbosacralis fájdalom biomarkereinek meghatározása a jövőben a személyre szabott ellátás részét képezheti. Tisztázásra vár, hogy a gyulladás a derékfájdalom melyik szakaszában és milyen mértékben van jelen, ez milyen módszerekkel mérhető, és vannak-e prognosztikus értékű biomarkerek.
\end{abstract}

Orv Hetil. 2020; 161(13): 483-490.

Kulcsszavak: derékfájdalom, lumboischialgia, biomarkerek, gyulladás, citokinek

\section{Serum biomarkers in acute low back pain and sciatica}

Inflammation contributes to the pathogenesis of low back pain and sciatica. Growing evidence suggests that elevated levels of some inflammatory biomarkers are associated with these conditions. Much of the research evaluating the association between pro- and anti-inflammatory cytokines, chemokines, other regulatory molecules, and low back pain and sciatica, focused on patients with chronic low back pain, while fewer studies addressed the issue of detectable biomarkers in the acute phase. Previous studies suggest that pro-inflammatory cytokines such as TNF- $\alpha$, IL- 6 , and IL-8 and anti-inflammatory IL-4 and IL-10 play an important role in the inflammatory response following intervertebral disc herniation. According to the approach of personalized medicine it is important to identify subsets of patients within the acute patient group regarding etiology, prognosis and treatment. In addition, if we can identify subgroups based on levels of pro-inflammatory biomarkers, where inflammation may be the leading cause of pain, we assume that this subgroup would likely be effectively treated with anti-inflammatory medication. The efficacy of TNF- $\alpha$ inhibitors and IL- 6 inhibitors in treating low back pain and sciatica has already been tested in clinical trials, but further studies are required. Overall, identification of circulating biomarkers of acute low back pain and sciatica may assist in refining personalized diagnosis and treatment. Further research is needed to evaluate the role of inflammation in acute low back pain and sciatica, to identify what methods are appropriate for evaluation in clinical practice, and whether there are biomarkers of prognostic value in these patients.

Keywords: low back pain, sciatica, biomarkers, inflammation, cytokines

Dénes K, Arányi Zs, Csillik A, Simó M, Debreczeni R, Tegze N, Bereczki D. [Serum biomarkers in acute low back pain and sciatica]. Orv Hetil. 2020; 161(13): 483-490.

(Beérkezett: 2019. október 17.; elfogadva: 2019. december 10.) 


\section{Rövidítések}

CCL2 = chemokine (C-C motif) ligand 2 (monocyte chemoattractant protein 1 ); CCL3 = chemokine (C-C motif) ligand 3 (macrophage inflammatory protein $1 \alpha$ ); CCL $4=$ chemokine (C-C motif) ligand 4 (macrophage inflammatory protein $1 \beta)$; CCL5 = chemokine $(\mathrm{C}-\mathrm{C}$ motif) ligand 5 ; $\mathrm{CX} 3 \mathrm{CLl}=$ chemokine $(\mathrm{C}-\mathrm{X} 3-\mathrm{C}$ motif $)$ ligand 1 ; CXCL6 $=$ chemokine (C-X-C motif) ligand 6; EMG = elektromiográfia; FGF2 = (fibroblast growth factor 2) fibroblastnövekedési faktor-2; GM-CSF = (granulocyte-macrophage colony-stimulating factor) granulocyta-macrophag kolónia stimuláló faktor; hsCRP = (high-sensitivity C-reactive protein) nagy érzékenységû C-reaktív fehérje; IL = interleukin; IQR = (interquartile range) interkvartilis tartomány; $\mathrm{MCPl}=$ monocyte chemotactic protein 1 (monocyte chemoattractant protein 1 ); MIPl $\beta=$ macrophage inflammatory protein $1 \beta ; M R=$ mágneses rezonancia; $\mathrm{mRNS}=(\mathrm{m}$ : messenger $)$ hírvivő ribonukleinsav; $\mathrm{NK}=$ (natural killer) természetes ölő(sejt); NSAID $=$ (nonsteroidal anti-inflammatory drug) nemszteroid gyulladáscsökkentó gyógyszer; NSLBP $=($ non-specific low back pain $)$ nem specifikus derékfájdalom; ODI $=$ (Oswestry Disability Index) Oswestry korlátozottsági mutató; PDGF $=$ (platelet-derived growth factor) thrombocytaeredetű növekedési faktor; PEA = (proximity extension assay) proximity extenziós vizsgálat; RANTES $=$ regulated on activation, normal $\mathrm{T}$ cell expressed and secreted; TNF $\alpha=$ tumornekrózisfaktor-alfa; VAS = vizuális analóg skála; VEGF = (vascular endothelial growth factor $)$ éreredetű endothelialis növekedési faktor

\section{Az akut lumbalis-lumbosacralis fájdalom}

Az akut lumbalis-lumbosacralis fájdalom az egyik leggyakoribb fájdalomszindróma, élettartam-prevalenciája 60 $70 \%$ közé tehető. Akár hetekre járásképtelen vagy munkaképtelen állapotot okozhat, így társadalmi terhe nagy, és jelentôs életminőség-rosszabbodással is jár. A fájdalom maradhat lokális (lumbago acuta), és járhat az érintett gyök lefutásának megfelelően az alsó végtagba sugárzó fájdalommal és egyéb tünetekkel (lumboischialgia) [1].

Klinikailag a lumbalis-lumbosacralis fájdalmat feloszthatjuk 4 hétig tartó akut szakaszra, 4 és 12 hét között fennálló fájdalom esetén szubakut stádiumról beszélünk, míg krónikusnak tartjuk, ha a fájdalom 12 héten túl is fennáll. Az akut lumbalis-lumbosacralis fájdalom kimenetele általában kedvező, gyakran 1-2 hét alatt csökken a fájdalom intenzitása. 6 hónapon belül azonban a betegek körülbelül $40 \%$-ánál visszatér a derékfájdalom. Ha a fájdalom krónikussá válik, a kezelés nehéz; az ilyen esetek társadalmi terhe nagy, jelentősen emelkedik az ellátás költsége [2].

Akut lumbago, lumboischialgia esetén nem diagnózisról, hanem egy tünetről, tünetcsoportról beszélünk, amely mögött számos etiológiai tényező állhat (1.ábra). Az esetek körülbelül $1 \%$-ának hátterében találunk valamilyen súlyos, szisztémás okot, például cauda equina compressiót/metastasist, spinalis epiduralis abscessust, osteomyelitist [3]. A ritka okok között felmerülhet még spondylitis ankylopoetica (Bechterew-kór), osteoarthritis, scoliosis és extraskeletalis okok, mint pancreatitis, nephrolithiasis, pyelonephritis, aorta abdominalis aneurysma, herpes zoster. Ilyen esetben a derékfájdalom mellett egyéb, az adott kórképre specifikus tünetek is fennállnak [4]. Az esetek körülbelül 10\%-ában az akut lumbalis-lumbosacralis fájdalom mögött compressiós csigolyatörés, spinalis stenosis és gyöki károsodás azonosítható [5].

$\mathrm{Az}$ akut lumbalis-lumbosacralis fájdalom hátterében a fennmaradó csaknem 85\%-ban specifikus etiológia, közvetlen kiváltó tényező egyértelmúen nem azonosítható. Ekkor beszélhetünk az ún. „non-specific low back pain”ről (NSLBP). Ilyen esetben a fájdalom a gerinc szerkezeti változásainak következménye, beleértve az intervertebralis discusokat, facet ízületeket, csigolyatesteket, szalagokat és izmokat [6].

Differenciáldiagnosztikai szempontból fontos elkülöníteni az olyan betegeket, akiknél valamilyen gerincvagy nem gerinceredetú, súlyos kórkép merül fel. Ennek megítélésében jelenthetnek segítséget a veszélyre utaló („red flag”-ként is említett) állapotok, tünetek. Ilyen alarmírozó tényezốk a fogyás, az anamnézisben szereplő tumor, az éjszaka vagy nyugalomban jelentkező fájdalom, az 50 éves kor feletti életkor, a jelentős trauma,

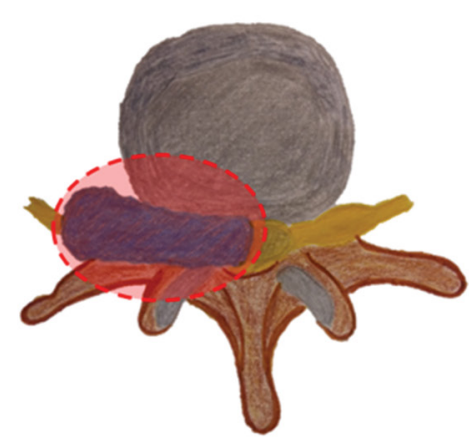

A

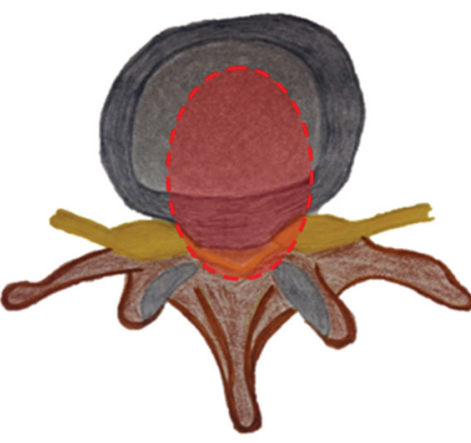

B

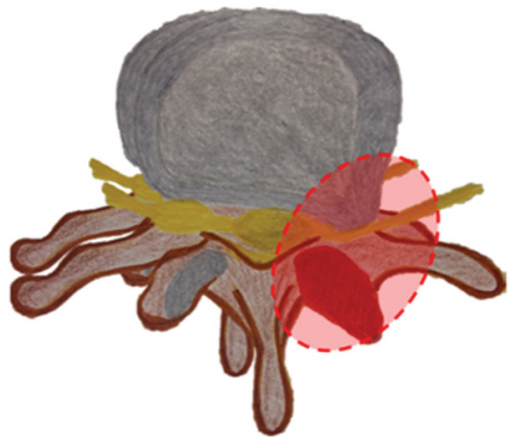

C myelitis). B) Egyéb gyakori okok (10\%, például compressiós csigolyatörés, spinalis stenosis, gyöki károsodás). C) Nem specifikus lumbalis-lumbosacralis fájdalom $(85 \%$, például intervertebralis discusok, facet ízületek, csigolyatestek, szalagok és izmok károsodása) 
1. táblázat

A lumbalis-lumbosacralis fájdalom kialakulásának komponense [13-15]

\begin{tabular}{ll}
\hline A károsodás jellege és szintje & A fájdalom oka \\
\hline Mechanikus gyöki compressio & $\begin{array}{l}\text { Az ideggyök compressiója } \\
\text { (a leggyakrabban discushernia } \\
\text { következtében) }\end{array}$ \\
\hline A gyök nem compressiós & $\begin{array}{l}\text { Az ideggyök szintjén létrejövő } \\
\text { idegkárosodás okozta neuropathiás } \\
\text { fájdalom }\end{array}$ \\
\hline Degeneratív és gyulladásos & $\begin{array}{l}\text { Discusdegeneráció vagy kisízületi } \\
\text { degeneráció okozta sejtszintú }\end{array}$ \\
jellegú, sejt- és molekuláris & $\begin{array}{l}\text { distress, következményes intracellu- } \\
\text { szintú változások }\end{array}$ \\
láris szignáltranszdukció- és \\
génexpresszió-változással, ami \\
elősegíti egyrészt a sérült discus \\
vascularisatióját és idegi elemek \\
beépülését, másrészt citokinek, \\
algeticus mediátorok upregulációját \\
indítja el, gyulladást, fájdalmat \\
okozva
\end{tabular}

a láz, a közeli anamnézisben húgyúti vagy bőr- és lágyrész-infekció. Szintén red flagként tekinthetünk a nyeregeloszlású érzészavarra, széklet- vagy vizeletincontinentiára, egyéb vizelési panaszokra, intravénás droghasználatra, progrediáló neurológiai tünetekre, szteroidok hosszan tartó alkalmazására, immunszuppresszióra, osteoporosisra [1].

Amennyiben a fájdalmat nem kíséri egyéb tünet (izomgyengeség vagy vizeletürítési zavar), a konzervatív kezelés a kezdeti választás, ennek eredménytelensége esetén jön szóba mütét.
Amennyiben a fájdalomhoz paresis és/vagy vegetatív zavar társul, és képalkotó vizsgálatokkal gyöki compressio igazolható, sürgős idegsebészeti beavatkozás indokolt. Az esetek döntő többségében azonban nincsenek ilyen tünetek, és konzervatív terápia választandó. A gyógyszeres kezelést rendszerint - a degeneratív kórképekben a leggyakrabban alkalmazott - nemszteroid gyulladáscsökkentőkkel (NSAID-ok) kezdjük [7]. Ugyanakkor az NSAID-oknak csak szerény fájdalomcsillapító hatásuk van akut lumbalis-lumbosacralis fájdalom esetén, valamint fontos figyelembe vennünk e gyógyszercsoport jól ismert gastrointestinalis, renalis és cardiovascularis mellékhatásprofilját is [8]. A fájdalomhoz a gyöki compressio mellett hozzájárul a paravertebralis izomzat tartós contractiója is („paravertebralis défense”), ezért eredményesebb kezelés várható, ha a fájdalomcsillapító kezelést izomlazítóval egészítjük ki [9, 10]. A paravertebralis izomzat tartós contractiójának kvantitatív jellemzésére felszíni elektromiográfiás (EMG) elektródos vizsgálat [11], a morfológia és a funkció (fasciculatio) megfigyelésére ultrahangvizsgálat alkalmazható [12].

Mivel a porckorongsérvhez és a gerincoszlop egyéb degeneratív elváltozásaihoz társuló lumbalis-lumbosacralis fájdalom patogenezisében szerepet játszik a gyulladás (1. táblázat) [13-15], és feltételezhető, hogy ilyen esetekben egyes gyulladásos mediátorok szintje a vérben mérhetően megemelkedik, a következőkben áttekintjük azon biomarkereket, melyekben változást találtak ebben a betegcsoportban (2. táblázat).

2. táblázat |Az összefoglalóban szereplő vizsgálatok jellemzői

\begin{tabular}{llllc}
\hline Szerzo, a megjelenés éve & A vizsgálat típusa & A fájdalom értékelése & A vizsgált biomarker & Esetszám \\
\hline $\mathrm{Zu}$, 2016 & Prospektív & VAS & TNF $\alpha$, IL4 & 262 \\
\hline Queiroz, 2017 & Keresztmetszeti & MPQ, NPS & TNF $\alpha$, IL1, IL6 & 155 \\
\hline Licciardone, 2012 & Keresztmetszeti & VAS & IL1 $\beta$, IL6, IL8, IL10, TNF $\alpha$ & 70 \\
\hline Wang, 2016 & Prospektív & ODI & IL4, IL6, IL8, IL10, TNF $\alpha$ & 108 \\
\hline Weber, 2016 & Keresztmetszeti & - & IL1 $\beta$, IL4, IL6, IL8, IL10, TNF $\alpha$ & 107 \\
\hline Pederson, 2015 & Prospektív & VAS & IL6, IL8 & 127 \\
\hline Park, 2007 & Keresztmetszeti & - & IL1 $\beta$, IL2, IL6, IL8, TNF $\alpha$ & 30 \\
\hline Kraychete, 2010 & Keresztmetszeti & NRS & TNF $\alpha$, IL1, IL6 & 33 \\
\hline Boisson, 2019 & Keresztmetszeti & - & TNF $\alpha$, IL1, IL6, IL8 & 34 \\
\hline Klyne, 2017 & Keresztmetszeti & VAS & TNF $\alpha$, IL1, IL6, CRP & 154 \\
\hline Peng, 2017 & Keresztmetszeti & VAS & CX3CL1, CCL2 & 46 \\
\hline Teodorczyk-Injeyan, 2018 & Keresztmetszeti & VAS & CCL2, CCL3, CCL4 & 63 \\
\hline Grad, 2016 & Keresztmetszeti & - & CCL5, CXCL6 & 80 \\
\hline
\end{tabular}

CCL2 = chemokine (C-C motif) ligand 2 (monocyte chemoattractant protein 1); CCL3 = chemokine (C-C motif) ligand 3 (macrophage inflammatory protein $1 \alpha)$; CCL4 = chemokine $(\mathrm{C}-\mathrm{C}$ motif) ligand 4 (macrophage inflammatory protein $1 \beta)$; CCL5 = chemokine $(\mathrm{C}-\mathrm{C}$ motif) ligand 5 ; CX3CLl = chemokine $(\mathrm{C}-\mathrm{X} 3-\mathrm{C}$ motif) ligand 1 ; CXCL6 = chemokine $(\mathrm{C}-\mathrm{X}-\mathrm{C}$ motif) ligand 6; IL = interleukin; MPQ = McGill Fájdalom Kérdő́iv; NPS = numerikus fájdalomskála; NRS = numerikus értékelőskála; ODI = Oswestry korlátozottsági mutató; TNF $\alpha=$ tumornekrózisfaktoralfa; VAS = vizuális analóg skála 


\section{Szérumbiomarkerek}

Az akut lumbalis-lumbosacralis fájdalomban a vérben mérhető egyes biomarkerek (nociceptin, citokinek, kemokinek, a sympathicus aktiváció markerei) jelentősen változnak, és feltehetően vannak olyan biomarkerek, amelyek szintje előre jelezheti a várható terápiás hatásosságot vagy hatástalanságot akut derékfájdalom esetén is, ezért segíthetnek a terápia megválasztásában, a műtéti indikáció korábbi felállításában, ezzel csökkentve a betegek szenvedésének hosszát.

A jelenlegi konzervatív terápia korlátait figyelembe véve, számos kutatás foglalkozik a különböző biomarkerek szerepével akut lumbalis-lumbosacralis fájdalomban. A biomarkerek új diagnosztikus eszközként jelenhetnek meg a megfelelő terápia kiválasztásában. Ezenfelül a fájdalom szenzitív indikátorai lehetnek, elkülönítve a pszichoszomatikus eredetû fájdalmat a valóban lumbalislumbosacralis eredetû fájdalomtól [16]. A biomarkerek segíthetnek egy adott betegség patogenezisének pontosabb feltérképezésében is, jelen vannak egy adott kórkép teljes kórlefolyása alatt. Nem utolsósorban a biomarkerek vizsgálata során nyert eredmények segíthetnek az adott egyénre szabott terápia kiválasztásában, az egyén betegségének típusától, klinikai stádiumától függően [13].

Egy biomarkernél elvárás a magas szenzitivitás és specificitás, emellett az adott biomarker értékelésének standardizáltnak, validáltnak, reprodukálhatónak kell lennie. Ezen jellemzők alapján a vérből mérhető különböző biomarkerek ideális eszköznek tünnek: a mintagyưjtés kivitelezhetőségével (vérvétel), ismételhetőségével, pontosságával előnyösebbek, mint egy invazív beavatkozást igénylő, szervspecifikus biológiai minta gyüjtése és tárolása [13].

Jungen és mtsai a lumbalis-lumbosacralis fájdalom szérumban mérhető biomarkereiről szóló kutatások áttekintését követően, az akut-szubakut lumbalis-lumbosacralis fájdalom (<12 hét) vizsgálatát helyeznék előtérbe a jövőben, annak ellenére, hogy a betegek nagy részének ez idő alatt jelentősen csökkennek a panaszai. Számottevő lehet, hogy az akut stádium esetén mely szérumbiomarkerek szintje emelkedett, és ezeknek van-e prognosztikai értékük például a fájdalom krónikussá válásában. A kutatások célja, hogy a közeljövőben a biomarkerek segítségével megjósolhatóvá váljon a lumbalis-lumbosacralis fájdalom klinikai lefolyása, illetve a betegcsoportok elkülönítése aszerint, hogy a konzervatív vagy a mútéti terápiától várhatunk jobb eredményt a kezelés során [14].

A gyulladást elősegítő különböző citokinek szabályozófehérjékként az akut lumbalis-lumbosacralis fájdalomban szerepet játszanak az immunsejtek által vezérelt gyulladásos válasz modulálásában [17]. Az akut lumbalis és lumbosacralis fájdalom és a pro-, valamint antiinflammatorikus citokinek mint biomarkerek közötti összefüggéseket több vizsgálat is értékelte. A leggyakrabban vizs- gált biomarkerek a következők voltak: interleukin-1 $\beta$ (IL1 $\beta$ ), interleukin-2 (IL2), interleukin-4 (IL4), interleukin-6 (IL6), interleukin-8 (IL8), interleukin-10 (IL10), interleukin-17 (IL17), interleukin-21 (IL21), monocyte chemotactic protein 1 (MCPl), tumornekrózisfaktoralfa (TNF $\alpha)$, a CX3CL1, CCL2 kemokinek. Ezenkívül a high-sensitivity $\mathrm{C}$-reactive proteint (hsCRP) mint a szisztémás gyulladás szenzitív markerét is vizsgálták.

\section{TNFa, IL6}

Az IL6 és a TNF $\alpha$ proinflammatorikus citokinek discusdegenerációban betöltött szerepe sokat kutatott terület, valamint ismert a szerepük a fájdalomérzés szabályozásában. Az IL6 - mint az akutfázis-reakció mediátora - elősegíti a monocyták macrophagokká történő differenciálódását, valamint a lymphocyták érésének aktiválásában is szerepet játszik [18]. A TNF $\alpha$ elősegíti a gyulladásos válaszreakciót, az idegek ödémáját, neuropathiás fájdalmat indukál, s citotoxikus hatása révén különböző sejtek apoptózisát idézi elő [19]. Perifériás idegsérülést követően számos neuropathiásfájdalom-modellben írták le a TNF $\alpha$ expressziójának upregulációját [20].

Queiroz és mtsai azt találták, hogy az akut lumbalislumbosacralis fájdalom intenzitása és súlyossága pozitívan korrelál a TNF $\alpha$ és az IL6 értékével. Ezenfelül összefüggést mutattak ki az IL6 szintje és a lumbalislumbosacralis fájdalom gyakorisága között. A leírt prospektív vizsgálatban azonban csak 65 év feletti nőbetegek vettek részt, így az adatok az egész populációra nézve korlátozottan értelmezhetők [21].

Egy másik vizsgálatban összefüggést találtak a krónikus, nem specifikus derékfájdalomban szenvedő betegek fájdalmának súlyossága és az IL6 szérumszintje között, de ez az összefüggés a TNF $\alpha$ esetén vizsgálatukban nem igazolódott, valószínúleg a vizsgálatban részt vevők fiatal életkora miatt (az átlagéletkor 38 év volt, az IQR: 23 év) [22].

Egy prospektív vizsgálatban 58 súlyos $(\mathrm{VAS}>3 / 10)$ és 50 enyhe (VAS $\leq 3 / 10)$ akut lumbalis-lumbosacralis fájdalomban szenvedő egyén szérum-TNF $\alpha$ - és -IL6-szintjét hasonlították össze egy 30 fóből álló kontrollcsoport mintáival. Az IL6 szérumfehérjét mindhárom csoportban detektálták; a mérések középértéke másfélszer magasabb volt a súlyos lumbalis-lumbosacralis fájdalomban szenvedők körében, mint az enyhe fájdalomnak minősített csoportban $(\mathrm{p}=0,02)$ és a kontrollcsoportban mért értékeknél $(p=0,03)$. Statisztikai különbség az enyhe fájdalomban szenvedők csoportja és a kontrollcsoport között nem volt. A TNF $\alpha$ szintje szintén mindhárom csoportban mérhető volt; a súlyos derékfájdalomban szenvedők között mért értékek megközelítóleg kétszer magasabbak voltak, mint az enyhe fájdalomban szenvedőknél $(\mathrm{p}<0,01)$ vagy az egészséges kontrollcsoportban $(\mathrm{p}<0,01)$ [23].

Szintén a TNF $\alpha$ szérumszintjét vizsgálták discushernia miatti microdiscectomia előtt, majd 1 és 12 hónappal a 
beavatkozás után [19]. A résztvevőket az előző vizsgálathoz hasonlóan egy enyhe fájdalomban szenvedő csoportra (VAS $<3 / 10 ; 66$ beteg) és egy súlyos fájdalomban szenvedő csoportra (VAS $\geq 3 / 10 ; 196$ beteg) osztották. A TNF $\alpha$ szintje a súlyos fájdalomban szenvedők körében magasabb volt, és bár a multidiszciplináris kezelés után az első hónapban a TNF $\alpha$ szintje jelentősen csökkent, a követés során végig magasabb maradt, mint az enyhe fájdalomban szenvedők csoportjában. Így a vizsgálat feltételezi a TNF $\alpha$ - mint proinflammatorikus mediátor központi szerepét a lumbalis-lumbosacralis fájdalom patogenezisében.

Weber és mtsai krónikus lumbalis-lumbosacralis fájdalomban szenvedő betegcsoportot hasonlítottak össze egészséges kontrollszemélyekkel. Egyrészt az IL6 szérumszintje szignifikánsabban magasabb volt a fájdalomban szenvedők között, mint a kontrollcsoportban, másrészt ez a vizsgálat közvetlen bizonyítékul szolgált arra a felvetésre, hogy a diagnózis függvényében változhatnak a szérumban mért citokinszintek. Weber és mtsai szérumcitokinszinteket hasonlítottak össze a vizsgált betegeiknél, különböző degeneratív discuselváltozások patogenezise alapján. Eredményeik szerint spinalis stenosis és egyéb degeneratív discus-rendellenességek esetén szignifikánsan magasabb IL6-szérumszinteket mértek, mint a discushernia okozta lumbalis-lumbosacralis fájdalom esetén, olyan kovariánsokat is figyelembe véve, mint a betegek életkora és testtömegindexe [24].

Egy prospektív vizsgálatban a discushernia diagnózisát követően 6 héttel, majd 12 hónappal az IL6 szintjének változását követték nyomon 127 betegnél. Az erősebb fájdalmat jelzők csoportjában (VAS $\geq 3 / 10)$ szignifikánsan magasabb IL6-szinteket mértek, amelyek a követési időszak alatt csökkentek ugyan, de végig magasabbak maradtak, mint a mérsékeltebb fájdalomról beszámolók (VAS $<3 / 10$ ) csoportjában. A figyelembe vett kovariánsok az IL6 esetében az életkor és a dohányzás volt [25].

\section{ILS}

Az IL8 szintén profinflammatorikus citokin, és az akut gyulladás mediátoraként képes a neutrophil granulocyták mozgósítására. Egyéb citokinek - mint az ILl $\beta$, TNF $\alpha-$ serkentik az IL8 szekrécióját [26].

Pedersen és mtsai az előzőleg hivatkozott vizsgálat során nemcsak az IL6 magasabb szintjét mutatták ki, hanem az IL8 emelkedett szintjét is. Vizsgálati eredményeik alapján feltételezik, hogy a discusherniatiót követően jelentkező, tartósan fennálló, szérumbeli emelkedett proinflammatorikus citokinek - vizsgálataik szerint az IL6 és az IL8 - összefüggésbe hozhatók a krónikus lumboischialgia kialakulásával. Vizsgálatukban az IL6 szérumszintjének változásában különbség volt a mérsékelt és a súlyos fájdalomban szenvedők csoportja között: míg a súlyos fájdalomban szenvedők IL6-szérumszintje a 6 . héten történt kontroll során jelentősen csökkent, addig a mérsékelt fájdalomban szenvedőknél ez az érték enyhén emelkedett. Ezzel szemben az IL8-szintekben jelentős csökkenést figyeltek meg a 6 . heti kontroll során a mérsékelt és a súlyos fájdalomban szenvedók csoportjában is [25].

Wang és mtsai vizsgálatában nem volt szignifikáns különbség az IL8-szintek között az enyhe és a súlyos derékfájdalomban szenvedők között, de a mért IL8szérumszintek középértéke magasabb volt a vizsgált betegcsoportban, mint az egészséges kontrollokban. A vizsgálatban a derékfájdalom okozta életminőségcsökkenés mérésére az Oswestry Disability Indexet (ODI) használták, amelynek értéke szignifikánsan korrelált a vizsgált IL6, TNF $\alpha$, IL10 szintjével, de nem korrelált az IL8- és IL4-szintekkel [23].

\section{ILI $\beta, I L 2$}

Az IL1ß-, illetve az egyéb, ILl-családba tartozó citokinek, valamint az IL2 szerepe a lumbalis-lumbosacralis fájdalomban nem egyértelmü. Az ILl $\beta$-nak feltehetőleg fontos szerepe van az olyan faktorok upregulációjában, amelyek a degenerált intervertebralis discus vascularisatiójáért, beidegzéséért felelősek [27].

Egy korábbi vizsgálatban emelkedett IL2-szérumszinteket találtak a discushernia miatt vizsgált betegcsoportban egészséges egyénekhez hasonlítva [28].

Egy kis esetszámú keresztmetszeti vizsgálatban discushernia miatt krónikus derékfájdalomban szenvedóket vizsgáltak, és mind a vérben, mind a liquorban emelkedett ILl-, IL6- és IL8-szinteket mértek [15].

Boisson és mtsai krónikus lumbalis-lumbosacralis fájdalomban szenvedők csoportját képalkotó vizsgálattal két alcsoportra osztották, MR-vizsgálattal igazolt discusdegeneráció jelenléte vagy hiánya alapján. A két alcsoport ILl $\beta$-, IL6-, IL8-, TNF $\alpha$-szérumszintjei között eltérést nem találtak [29].

Akut (legfeljebb 2 hete fennálló) lumbalis-lumbosacralis fájdalom miatt kezelt 99 fös betegcsoport IL1 $\beta$-, IL6-, TNF $\alpha$-szérumszintjeit hasonlították össze egy 55 fös, egészséges személyekből álló kontrollcsoport mintáival. Az ILl $\beta$-szintekben nem találtak különbséget a vizsgált két csoport között. Az IL6 csak a súlyos fájdalomban szenvedők csoportjában (VAS $\geq 4 / 10$ ) volt magasabb, az enyhe fájdalmat jelzőknél (VAS $<4 / 10$ ) és a kontrollcsoportban nem. A kutatás felvetette az IL6 lehetséges antiinflammatorikus szerepét is, mert az IL6 szérumszintje a fájdalom intenzitásával nem lineárisan korrelált. A TNF $\alpha$ szintje szintén magasabb volt a vizsgált panaszos egyéneknél, mint a kontrollcsoportban [30].

\section{IL4, IL10 mint antiinflammatorikus citokinek}

Az IL4 és IL10 citokinek antiinflammatorikus hatásúak, aktivált macrophagok és monocyták termékei; egyrészt feltehetőleg gátolják a proinflammatorikus citokinek által indukált gyulladásos választ a proinflammatorikus citokinek szintézisének gátlása révén. Másrészt gátolják a 
monocyta/macrophag aktivitást, a neutrophil granulocyták citokintermelését és a Thl-sejtek által mediált immunválaszt. Harmadrészt B-lymphocytákat aktiválnak, és serkentik a natural killer sejtek (NK-sejtek) múködését [31]. Negyedrészt az IL4 különböző opioid receptorok transzkripciójának upregulációja révén közvetlenül befolyásolja az endogén opioid rendszert. Ezáltal az antiinflammatorikus citokinek természetes fájdalomcsillapító szereppel bírnak azáltal, hogy befolyásolják az endogén opioid rendszer aktivitását és szenzitivitását [23].

Wang és mtsai emelkedettebb IL4- és IL10-szérumszinteket írtak le enyhe lumbalis-lumbosacralis fájdalomban szenvedők csoportjában, mint a súlyos fájdalomban szenvedőknél. Az ILl0 szintje negatívan korrelált az általuk használt ODI értékével. Eredményeik alapján feltételezik az antiinflammatorikus citokinek fájdalomcsökkentő hatását, ami szintén előre jelezheti a kezelés kedvezőbb kimenetelét [23]. Az IL4 és az IL10 antiinflammatorikus, ezáltal feltételezhetően analgetikus hatását korábban neuropathiák vizsgálatakor is megállapították: fájdalmat nem okozó neuropathia esetén az IL4 és az ILl0 magasabb szérum-mRNS-szintjét találták [32].

\section{Kemokinek, egyéb vizsgált, lehetséges biomarkerek}

Szöveti sérüléshez társuló gyulladásos válaszreakciót az idegek megnövekedett ingerelhetősége, illetve az adott helyen a leukocyták felszaporodása kíséri. A citokinek egy alcsoportját képező kemokinek vesznek részt ennek a folyamatnak a koordinálásában [33]. A kemokineket aminosav-szerkezetük, illetve receptoraik szerint négy csoportra oszthatjuk (CC, XC, CXC és CX3C; receptoraik: CCR, XCR, CXCR, CX3CR). Mind a gyulladásos válaszreakció kezdeti, mind a későbbi lépéseinél jelen vannak kemokinek, elősegítve különböző sejtek kilépését a véráramból a szövetekbe [34].

A kemokinek közül a CX3C és CC alcsoportok a legszélesebb körben vizsgáltak, különösen a CX3CLl (C-X3-C motif ligand 1), vagyis a fraktalkin. A fraktalkin egyedi szerkezettel bír a kemokinek között, receptorai mind a központi, mind a perifériás idegrendszer sejtjein, de endothelsejteken, lymphocytákon is expresszálódnak. A CCL2 (C-C motif ligand 2) - más néven monocyte chemoattractant protein 1 vagy monocyte chemotactic protein 1 (MCPl) - kulcsszerepet játszik a krónikus fájdalom patomechanizmusában, a CCR2-receptor serkentése révén [35].

Peng és mtsai a CX3CLl és a CCL2 (MCPl) szérumszintjeit vizsgálták enyhe-közepes $(\mathrm{VAS}<7 / 10)$ és súlyos (VAS $\geq 7 / 10$ ) discushernia miatt kialakult derékfájdalomban szenvedő betegeknél, egy egészséges kontrollcsoporttal összehasonlítva. Mindkét kemokin szintje magasabb volt a derékfájdalomban szenvedők körében, mint a kontrollcsoportban, valamint szintjük a fájdalom súlyosságával is korrelált [35].
Egyéb kemokinalcsoportba tartoznak még az endothelsejtek felszínén expresszálódó macrophage inflammatory protein (CC chemokine ligand CCL2), macrophage inflammatory proteins $1 \alpha$ (CCL3) és $1 \beta$ (CCL4). A kemokinek elősegítik a gyulladást, a gyulladásos sejtek és a neuronok közötti kommunikációban, a fájdalom transzmissziójában játszanak szerepet. A fájdalom és a különböző kemokinek kapcsolatát eddig még kevés vizsgálat elemezte [36].

Akut és krónikus derékfájdalomban szenvedók szérummintáiban összehasonlítva a CCL2, CCL3, CCL4 kemokinek szintjeit egy kontrollcsoport mintáival, szignifikánsan emelkedett kemokinszinteket írtak le a fájdalomban szenvedők csoportjában (63 fó). Ezenfelül a CCL4 szintje jelentősen magasabb volt az akut derékfájdalomban szenvedők körében, mint a krónikus derékfájdalom miatt vizsgált egyénekben [36].

A CCL5, vagy RANTES (regulated on activation, normal T cell expressed and secreted) gyulladás hatására expresszálódik, és katabolikus hatása van. A rheumatoid arthritis fontos, szérumból mérhető prognosztikus faktora [17]. A CCL5 és a CXCL6 kemokinek sérült discussejtekból szekretálódnak. Grad és mtsai keresztmetszeti vizsgálatukban MR-vizsgálattal igazolt discusdegeneráció miatt derékfájdalomban szenvedő 40 fős betegcsoport CCL5- és CXCL6-szérumszintjét hasonlították össze egy 40 fös kontrollcsoport mintáival. Mindkét kemokin szérumszintje emelkedett volt a discusdegeneráció miatt kezelt betegcsoportban, de a biomarkerek és a fájdalom súlyosságának kapcsolatát nem értékelték [37].

Lumbalis discushernia miatt kezelt betegcsoportban 92 gyulladásos fehérje szérumszintjét vizsgálták proximity extension assay (PEA) módszerrel. 13 fehérjét azonosítottak, amelyek szintje szignifikánsan magasabb volt egy évvel a panaszok jelentkezése után. A citokinprofil különbözött a gyógyult, fájdalomban nem szenvedők alcsoportja, illetve a között az alcsoport között, amelyben a derékfájdalom krónikussá vált. Így e vizsgálat felvetette, hogy az eltérô patogenezisû lumbalis-lumbosacralis fájdalomban szenvedő betegek szérumfehérjéinek a PEA-módszerrel való átfogó meghatározása használható lehet a prognózis felállításában és a betegek számára legmegfelelőbb kezelés kiválasztásában [38].

Egy eset-kontroll vizsgálatban akut myofascialis fájdalom szindróma miatt kezelt betegcsoport (37 fó) gyulladásos biomarkereit és különböző növekedési faktorok szérumszintjét hasonlították össze egy egészséges kontrollcsoport mintáival (21 fó). Az IL6, TNF $\alpha$, IL12, MCP1, IL8 citokineken és kemokinen kívül a GM-CSF (granulocyte-macrophage colony-stimulating factor) és a MIPl $\beta$ (macrophage inflammatory protein $1 \beta$ ) szérumban mérhető szintje is jelentősen emelkedett volt a kontrollcsoporthoz képest. A növekedési faktorok vizsgálatát követően az FGF2 (fibroblast growth factor 2), a PDGF (platelet-derived growth factor) és a VEGF (vascular endothelial growth factor) szignifikánsan ma- 
gasabb szintje is igazolódott a myofascialis fájdalom szindrómában szenvedők vizsgált csoportjában [39].

A discushernia és a gerincoszlop egyéb degeneratív elváltozásaihoz társuló derékfájdalom patogenezisében szerepet játszik a gyulladás. Ehhez kapcsolódóan több vizsgálat is feltételezi, hogy egyes gyulladásos mediátorok szintje a vérben is mérhető. Akut lumbalis-lumbosacralis fájdalomban jelenleg a konzervatív kezelés hatásossága kiszámíthatatlan, gyakoriak a relapsusok; a mútéti kezelés anatómiai korrekcióval jár ugyan, és enyhítheti a fájdalmat, de invazív beavatkozást jelent, és költséges. A spinalis degeneráció és az akut lumbalislumbosacralis fájdalom biomarkerei egy jövőbeli, személyre szabott terápia részét képezhetik [13]. A fenti vizsgálatok alapján a proinflammatorikus TNF $\alpha$, IL6 és IL8 és az antiinflammatorikus IL4 és IL10 citokinek játszhatnak fontos szerepet a discusherniatiót követó gyulladásos válaszban [18]. Ugyanakkor a gyulladásos mediátorok prognosztikus szerepe az akut lumbalis-lumbosacralis fájdalomban további vizsgálatokra szorul. Tisztázásra vár, hogy a gyulladás a derékfájdalom melyik szakaszában és milyen mértékben van jelen, ez milyen módszerekkel mérhető, és vannak-e prognosztikus értékü biomarkerek.

Anyagi támogatás: A kapcsolódó kutatómunka részben a 2018-1.3.1.-VKE-2018-00030 számú pályázat támogatásával készült. A kutatást az Emberi Erőforrások Minisztériuma által meghirdetett Felsőoktatási Intézményi Kiválósági Program is támogatta, a Semmelweis Egyetem neurológiai tématerületi programja keretében.

Szerzői munkamegosztás: D. K.: Irodalomkeresés, a kézirat első változatának megfogalmazása. A. Zs., Cs. A., S. M., D. R., T. N., B. D.: A kézirat egymást követő verzióinak véleményezése, kiegészítése. A cikk végleges változatát valamennyi szerző elolvasta és jóváhagyta.

Érdekeltségek: A szerző́knek nincsenek érdekeltségeik.

\section{Irodalom}

[1] Kinkade S. Evaluation and treatment of acute low back pain. Am Fam Physician 2007; 75: 1181-1188.

[2] Carey TS, Garrett JM, Jackman A, et al. Recurrence and care seeking after acute back pain: results of a long-term follow-up study. North Carolina Back Pain Project. Med Care 1999; 37: 157-164.

[3] Sun JC, Xu T, Chen KF, et al. Assessment of cauda equina syndrome progression pattern to improve diagnosis. Spine 2014; 39: 596-602.

[4] Chou R. Low back pain. Ann Intern Med. 2014; 160: ITC6-1.

[5] Ropper AH, Zafonte RD. Sciatica. N Engl J Med. 2015; 372: 1240-1248.

[6] Balagué F, Mannion AF, Pellisé F, et al. Non-specific low back pain. Lancet 2012; 379: 482-491.

[7] Sütő G. Non-steroidal anti-inflammatory drugs for relieving pain in musculoskeletal disorders. [Nemszteroid gyulladáscsökkentő szerek a mozgásszervi fájdalom csillapításában.] Orv Hetil. 2019; 160: 855-860. [Hungarian]

[8] Szamosi Sz. Recommendation for the substantial choice between various nonsteroidal antiinflammatory drugs based on their safety profile. [A nemszteroid gyulladáscsökkentő gyógyszerek kiválasztásának szempontjai a biztonságosság tükrében.] Orv Hetil. 2018; 159: 1783-1788. [Hungarian]

[9] Abdel Shaheed C, Maher CG, Williams KA, et al. Efficacy and tolerability of muscle relaxants for low back pain: systematic review and meta-analysis. Eur J Pain 2017; 21: 228-237.

[10] van Tulder MW, Touray T, Furlan AD, et al. Muscle relaxants for non-specific low back pain. Cochrane Database Syst Rev. 2003; 2003: CD004252.

[11] Bazrgari B, Xia T. Application of advanced biomechanical methods in studying low back pain - recent development in estimation of lower back loads and large-array surface electromyography and findings. J Pain Res. 2017; 10: 1677-1685.

[12] Johansson MT, Ellegaard HR, Tankisi H, et al. Fasciculations in nerve and muscle disorders - a prospective study of muscle ultrasound compared to electromyography. Clin Neurophysiol. 2017; 128: 2250-2257.

[13] Khan AN, Jacobsen HE, Khan J, et al. Inflammatory biomarkers of low back pain and disc degeneration: a review. Ann N Y Acad Sci. 2017; 1410: 68-84.

[14] Jungen MJ, Ter Meulen BC, van Osch T, et al. Inflammatory biomarkers in patients with sciatica: a systematic review. BMC Musculoskelet Disord. 2019; 20: 156

[15] Kraychete DC, Sakata RK, Issy AM, et al. Serum cytokine levels in patients with chronic low back pain due to herniated disc: analytical cross-sectional study. Sao Paulo Med J. 2010; 128: 259-262.

[16] Biomarkers Definitions Working Group. Biomarkers and surrogate endpoints: preferred definitions and conceptual framework. Clin Pharmacol Ther. 2001; 69: 89-95.

[17] van den Berg R, Jongbloed EM, de Schepper EI, et al. The association between pro-inflammatory biomarkers and nonspecific low back pain: a systematic review. Spine J. 2018; 18: 21402151.

[18] Shamji MF, Setton LA, Jarvis W, et al. Proinflammatory cytokine expression profile in degenerated and herniated human intervertebral disc tissues. Arthritis Rheum. 2010; 62: 1974-1982.

[19] Zu B, Pan H, Zhang XJ, et al. Serum levels of the inflammatory cytokines in patients with lumbar radicular pain due to disc herniation. Asian Spine J. 2016; 10: 843-849.

[20] Andrade P, Hoogland G, Del Rosario JS, et al. Tumor necrosis factor- $\alpha$ inhibitors alleviation of experimentally induced neuropathic pain is associated with modulation of TNF receptor expression. J Neurosci Res. 2014; 92: 1490-1498.

[21] Queiroz BZ, Pereira DS, Rosa NM, et al. Inflammatory mediators and pain in the first year after acute episode of low-back pain in elderly women: longitudinal data from back complaints in the elders - Brazil. Am J Phys Med Rehabil. 2017; 96: 535-540.

[22] Licciardone JC, Kearns CM, Hodge LM, et al. Associations of cytokine concentrations with key osteopathic lesions and clinical outcomes in patients with nonspecific chronic low back pain: results from the OSTEOPATHIC Trial. J Am Osteopath Assoc. 2012; 112: 596-605. [Erratum J Am Osteopath Assoc. 2017; 117: 350.]

[23] Wang K, Bao JP, Yang S, et al. A cohort study comparing the serum levels of pro- or anti-inflammatory cytokines in patients with lumbar radicular pain and healthy subjects. Eur Spine J. 2016; 25: 1428-1434.

[24] Weber KT, Alipui DO, Sison CP, et al. Serum levels of the proinflammatory cytokine interleukin- 6 vary based on diagnoses in individuals with lumbar intervertebral disc diseases. Arthritis Res Ther. 2016; 18: 3 .

[25] Pedersen LM, Schistad E, Jacobsen LM, et al. Serum levels of the pro-inflammatory interleukins 6 (IL-6) and -8 (IL-8) in patients 
with lumbar radicular pain due to disc herniation: a 12 -month prospective study. Brain Behav Immun. 2015; 46: 132-136.

[26] Brisby H, Olmarker K, Larsson K, et al. Proinflammatory cytokines in cerebrospinal fluid and serum in patients with disc herniation and sciatica. Eur Spine J. 2002; 11: 62-66.

[27] Binch AL, Cole AA, Breakwell LM, et al. Expression and regulation of neurotrophic and angiogenic factors during human intervertebral disc degeneration. Arthritis Res Ther. 2014; 16: 416.

[28] Park MS, Lee HM, Hahn SB, et al. The association of the activation-inducible tumor necrosis factor receptor and ligand with lumbar disc herniation. Yonsei Med J. 2007; 48: 839-846.

[29] Boisson M, Borderie D, Henrotin Y, et al. Serum biomarkers in people with chronic low back pain and Modic 1 changes: a casecontrol study. Sci Rep. 2019; 9: 10005.

[30] Klyne DM, Barbe MF, Hodges PW. Systemic inflammatory profiles and their relationships with demographic, behavioural and clinical features in acute low back pain. Brain Behav Immun. 2017; 60: 84-92.

[31] Üçeyler N, Riediger N, Kafke W, et al. Differential gene expression of cytokines and neurotrophic factors in nerve and skin of patients with peripheral neuropathies. J Neurol. 2015; 262: 203-212.

[32] Üçeyler N, Rogausch JP, Toyka KV, et al. Differential expression of cytokines in painful and painless neuropathies. Neurology 2007; 69: 42-49.
[33] Turner MD, Nedjai B, Hurst T, et al. Cytokines and chemokines: at the crossroads of cell signalling and inflammatory disease. Biochim Biophys Acta 2014; 1843: 2563-2582.

[34] Zlotnik A, Yoshie O. The chemokine superfamily revisited. Immunity 2012; 36: 705-716.

[35] Peng ZY, Chen R, Fang ZZ, et al. Increased local expressions of CX3CL1 and CCL2 are related to clinical severity in lumbar disk herniation patients with sciatic pain. J Pain Res. 2017; 10: 157165.

[36] Teodorczyk-Injeyan JA, McGregor M, Triano JJ, et al. Elevated production of nociceptive $\mathrm{CC}$ chemokines and $\mathrm{sE}$-selectin in patients with low back pain and the effects of spinal manipulation: a nonrandomized clinical trial. Clin J Pain 2018; 34: 68-75.

[37] Grad S, Bow C, Karppinen J, et al. Systemic blood plasma CCL5 and CXCL6: potential biomarkers for human lumbar disc degeneration. Eur Cell Mater. 2016; 31: 1-10.

[38] Moen A, Lind AL, Thulin M, et al. Inflammatory serum protein profiling of patients with lumbar radicular pain one year after disc herniation. Int J Inflam. 2016; 2016: 3874964.

[39] Grosman-Rimon L, Parkinson W, Upadhye S, et al. Circulating biomarkers in acute myofascial pain: a case-control study. Medicine (Baltimore) 2016; 95: e4650.

(Bereczki Dániel dr., Budapest, Balassa u. 6., 1083 e-mail: bereczki.daniel@med.semmelweis-univ.hu)

\section{Pályázati felhívás}

Dr. Fehér János professzornak, a Semmelweis Egyetem II. sz. Belgyógyászati Klinikája volt igazgatójának, az Orvosi Hetilap volt föszerkesztőjének emlékére 2011-ben alapítvány létesült.

A Dr. Fehér János Emlékére Alapítvány fő célja a belgyógyászat, különösen a hepatológia szabad gyökös és immunológiai vonatkozású témaköreinek kutatása, fejlesztése, támogatása, illetve ösztönzése oly módon, hogy az alapítvány kamatából fiatal egyetemi oktatók, PhD-hallgatók és orvostanhallgatók részesüljenek.

\section{A pályázatok benyújtásának határideje: 2020. április 15.}

A dolgozatot „Dr. Fehér János pályázat” megjelöléssel kell benyújtani, és a pályázathoz mellékelni kell a pályázó önéletrajzát is.

A dolgozatot a Dr. Fehér János Emlékére Alapítvány Kuratóriuma elnökének (Dr. Hagymási Krisztina) vagy titkárának (Dr. Lengyel Gabriella) kell eljuttatni. Beküldési cím: Semmelweis Egyetem, II. Belgyógyászati Klinika 1088 Budapest, Szentkirályi u. 46.

A díj odaítéléséről a kuratórium dönt. A díj átadására az Orosi Hetilap Markusovszky-ünnepségén kerül sor, ahol a nyertes pályázó 5 perces előadásban foglalhatja össze az eredményeit.

A cikk a Creative Commons Attribution 4.0 International License (https://creativecommons.org/licenses/by/4.0/) feltételei szerint publikált Open Access közlemény, melynek szellemében a cikk bármilyen médiumban szabadon felhasználható, megosztható és újraközölhető, feltéve, hogy az eredeti szerző és a közlés helye, illetve a CC License linkje és az esetlegesen végrehajtott módosítások feltüntetésre kerülnek. (SID_1) 